\title{
REVIEW
}

\section{Progenitor Cell Dysfunctions Underlie Some Diabetic Complications}

\author{
Melanie Rodrigues, Victor W. Wong, Robert C. Rennert, Christopher R. Davis, Michael T. Longaker, and Geoffrey C. Gurtner
}

From the Division of Plastic and Reconstructive Surgery, Department of Surgery, Stanford University, Stanford, California

\author{
Accepted for publication \\ May 4, 2015. \\ Address correspondence to \\ Geoffrey C. Gurtner, M.D. \\ F.A.C.S., Department of \\ Surgery, Stanford University \\ School of Medicine, Stanford \\ University, Stanford, CA. \\ E-mail: ggurtner@stanford.edu.
}

\begin{abstract}
Stem cells and progenitor cells are integral to tissue homeostasis and repair. They contribute to health through their ability to self-renew and commit to specialized effector cells. Recently, defects in a variety of progenitor cell populations have been described in both preclinical and human diabetes. These deficits affect multiple aspects of stem cell biology, including quiescence, renewal, and differentiation, as well as homing, cytokine production, and neovascularization, through mechanisms that are still unclear. More important, stem cell aberrations resulting from diabetes have direct implications on tissue function and seem to persist even after return to normoglycemia. Understanding how diabetes alters stem cell signaling and homeostasis is critical for understanding the complex pathophysiology of many diabetic complications. Moreover, the success of cell-based therapies will depend on a more comprehensive understanding of these deficiencies. This review has three goals: to analyze stem cell pathways dysregulated during diabetes, to highlight the effects of hyperglycemic memory on stem cells, and to define ways of using stem cell therapy to overcome diabetic complications. (Am J Pathol 2015, 185: 2607-2618; http://dx.doi.org/10.1016/j.ajpath.2015.05.003)
\end{abstract}

Diabetes is characterized by insulin resistance and hyperglycemia, and affects a diverse array of cells, leading to a myriad of tissue complications. These include, but are not limited to, cardiac arrest, stroke, nephropathy, retinopathy, and non-traumatic lower limb amputations. ${ }^{1}$ Results from randomized clinical trials indicate that adequate glycemic control in diabetic patients reduces the risk of developing one or several of these complications..$^{2-4}$ The Diabetes Control and Complications Trial reports a reduction in the development or progression of diabetic nephropathy (50\% reduction), neuropathy $(60 \%$ reduction), and retinopathy (76\% reduction) after intensive glycemic control. ${ }^{5}$ However, $33 \%$ of Americans with diabetes remain undiagnosed, approximately $12 \%$ of US adults with diabetes exhibit poor glycemic control, and different medical organizations recommend different glycemic targets, increasing the occurrence of diabetic complications. ${ }^{1,6}$ Furthermore, a substantial fraction of patients develop progressive disease despite lowering glycemia, making it critical to study the cellular and molecular modifications that lead to diabetic complications. ${ }^{7-9}$
At the tissue level, vascular complications are the most serious manifestations of diabetes. ${ }^{10}$ Closer analysis at the cellular and molecular levels reveals that diabetic complications emerge from alterations in the intracellular signaling of a wider range of cell types. These cellular changes, in turn, arise from variations in the oxidation reduction and glycation state after exposure to hyperglycemia. ${ }^{11,12}$ Stem cells and progenitor cells are one of the more critical cell types to be affected by the glycemic modulations. ${ }^{13-15}$ This review addresses the emerging role of hyperglycemia on stem and progenitor cells, and the subsequent consequence of these changes on specific tissues.

\footnotetext{
Supported by NIH US Health and Human Services Department (HHS) National Institute of Diabetes and Digestive and Kidney Diseases (NIDDK) grant R01-DK074095/DK/NIDDK NIH HHS/United States, NIH HHS National Institute on Aging (NIA) grant R01-AG025016/AG/NIA NIH HHS/United States, and NIH HHS National Institute of Biomedical Imaging and Bioengineering (NIBIB) grant R01-EB005718/EB/NIBIB NIH HHS/United States.

Disclosures: None declared.

This article is part of a review series on regenerative medicine.
} 


\section{Stem Cell Contribution toward Regeneration and Repair}

Stem cells are the fundamental building blocks of tissue and defined by the ability to self-renew and the capacity to differentiate into progenitor cells that perform specific functions. True stem cells exhibit both these criteria, whereas progenitor cells or transit amplifying cells cannot self-renew in perpetuity. In the adult tissue, hematopoietic stem cells (HSCs) are the only cells known to repopulate the hematopoietic system, making them indispensable for repair and regeneration. ${ }^{16,17} \mathrm{HSCs}$ reside in the bone marrow, harbored by mesenchymal stromal cells (MSCs) with multipotent differentiation capacity. ${ }^{18}$ Herein, MSCs are believed to regulate the quiescence, proliferative potential, differentiation fate, and trafficking of HSCs through release of growth factors and chemokines. ${ }^{19,20}$

MSCs have also been isolated from fetal bone marrow, umbilical cord, placenta, and adipose tissue. They are provasculogenic, and facilitate angiogenesis after injury by functioning as pericytes. ${ }^{21}$ There is consensus on the basis of correlative tissue engineering, in vitro observations, and stem cell niche studies that MSCs contribute to local healing. ${ }^{22-24}$ However, the presence of MSCs in circulation is disputed. ${ }^{25-27}$ Because of the rare distribution of MSCs and the lack of definite markers for their identification in vivo, it remains difficult to determine whether these cells are indispensable for physiological regeneration at distant sites.

In addition to HSCs and MSCs, the bone marrow is also reported to contain endothelial precursor cells that circulate and aid in physiological and pathological neovascularization. ${ }^{28,29}$ Early endothelial precursor cell studies reported migration of these cells toward ischemia after injury, where they initiated vasculogenesis, the process of de novo vessel formation. ${ }^{30,31}$ However, the identity and existence of endothelial precursor cells have since been highly controversial, especially because the cells are derived through inconsistent protocols of expanding peripheral blood mononuclear cells. It is suggested, on the basis of discrepancies in surface marker identity, that these cells either do not circulate or are most likely monocytes or macrophages. $^{32,33}$

\section{Stem Cell Renewal}

Stem cells have the unique ability to reside in a quiescent $\mathrm{G}_{0}$ phase. Injury and tissue loss triggers their activation, and the cells enter the $G_{1}$ phase of the cell cycle, where they commit to either self-renewal or differentiation. ${ }^{34}$ Between the $G_{0}$ and $G_{1}$ phases of the cell cycle exists a newly described reversible phase of quiescence called the $\mathrm{G}_{\text {alert }}$ phase that is proposed to prime stem cells for either renewal or differentiation. ${ }^{35}$ Imbalance within these states can have pathological consequences on the body's ability to repair injured tissues. $^{36-38}$

\section{Stem Cell Bioenergetics}

There is an increasing emphasis on glucose metabolism in determining stem cell fate. ${ }^{39}$ A stem cell in an undifferentiated state, a progenitor committed to differentiation, and a terminally differentiated cell are expected to possess varying metabolic demands. Thus, stem cells would benefit from flexibility in metabolic pathways, with a balance of anabolic processes for building and catabolic processes to ensure supply of bioenergetics resources. Complete consumption of substrates, including glucose, that occur during oxidative phosphorylation may be insufficient to support the energy requirements of the stem cell. Instead, stem cells are postulated to prefer glycolysis, which allows for partial breakdown of glucose and shunting of intermediates through the pentose phosphate pathway. This allows for both the catabolic process of ATP generation and the production of substrates for anabolic processes. ${ }^{40,41}$

When stem cells switch the bulk of their ATP generation from glycolysis to oxidative phosphorylation, they are found to undergo differentiation. ${ }^{41,42}$ Similarly, the balance between ATP/AMP ratios has been found to control the transition between quiescence and proliferation. ${ }^{43}$ Therefore, maintaining a balance between glycolysis and oxidative phosphorylation offers a potential strategy to deterministically alter the fate of downstream proliferation versus differentiation and improve homeostasis and regeneration. Regulations of these pathways have implications during hyperglycemia and diabetes.

Other nutrient- and glucose-sensing mechanisms detailing the exit from quiescence and the activation of stem cells are being actively investigated. Induction of autophagy, the process of self-eating of cellular components, is emerging as one of the alternate mechanisms by which stem cells rapidly meet their bioenergetics demands and get activated. This mode of activation has been studied in embryonic stem cells, HSCs, MSCs, and neural stem cells (NSCs). ${ }^{44-46}$ Correlative studies demonstrate that aging and diabetes perturb and inhibit the autophagic machinery of cells. ${ }^{47,48}$ This would suggest that a specific disruption of the autophagic signaling in stem cells in response to the diabetic state might contribute to the dysfunctional stem cell phenotype.

\section{Altered Stem Cell Dynamics in Diabetes Results in Diabetic Complications}

Diabetes is associated with a myriad of tissue-specific complications. These include, but are not limited to, renal failure, blindness, neuropathy, atherosclerosis, and cardiac failure. Diabetes also results in generic complications, such as impaired neovascularization and microvascular complications, resulting in ulcers and chronic nonhealing wounds. There is increasing evidence that suggests that stem cell dysfunction underlies some of these complications. Exposure to hyperglycemia is found to produce both stem cell deficits 
Stem Cell Niche

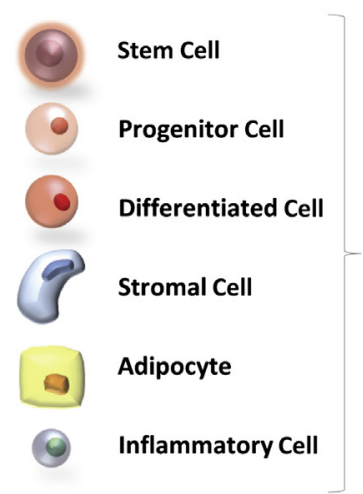

Diabetic Stem Cell Niche

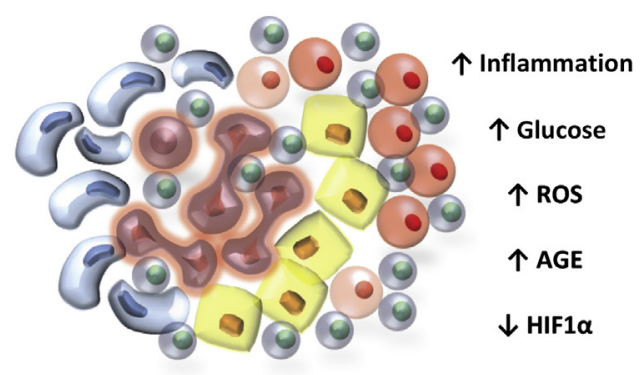

Stem Cell Proliferation and Differentiation

Figure 1 Diabetes disrupts stem cell dynamics. Altered metabolic signaling in the stem cell niche after exposure to high glucose leads to the loss of stem cell quiescence and activation of differentiation, preferentially into adipocytes. There is also an increased presence of inflammatory cells within the stem cell niche after diabetes. AGE, advanced glycation end product; HIF, hypoxia-inducible factor; ROS, reactive oxygen species.

and alterations in the tissue microenvironment surrounding the stem cell. ${ }^{49-53}$ These impairments include, but are not limited to, changes in migration, recruitment, survival, selfrenewal, and differentiation capacity (Figure 1). This section details the changes produced by hyperglycemia in stem cells of the bone marrow, nervous system, bone, and heart.

\section{Hyperglycemic Impairments in Bone Marrow Stem Cells}

Diabetes produces a global remodeling of the bone marrow. From a stem cell standpoint, there is decreased efflux of diabetic progenitors from the marrow and reduced vasculogenic potential of these cells. ${ }^{54}$ Murine models of both type 1 and type 2 diabetes confirm this impaired egress of bone marrow progenitors after injury. ${ }^{13,55}$ Furthermore, clinical studies demonstrate that diabetes causes a reduction of hematopoietic tissue, increased fat deposition, and microvascular rarefaction in the bone marrow. ${ }^{56}$ These changes have a cumulative negative outcome on progenitor cells.

More important, diabetic patients with satisfactory glycemic control display more circulatory progenitors than patients with poor glycemic control, but fewer progenitors compared with nondiabetics. ${ }^{57}$ This suggests that normalizing glucose levels after hyperglycemia may not be sufficient to normalize tissue homeostasis.

\section{Hyperglycemic Impairments in NSCs}

The effect of diabetes on stem cells is not limited to the adult tissue alone. Maternal diabetes produces a hyperglycemic environment for the developing embryo and has been linked to congenital malformations in various tissues, including the nervous system. NSCs are self-renewing multipotent cells that produce neurons and glia (astrocytes and oligodendrocytes) of the central nervous system. Exposure of the fetus to high glucose has been found to impair NSCs in the developing brain, altering cell fate and producing neural tube defects. These include spina bifida, anencephaly, craniorachischisis, and encephalocele. ${ }^{58}$ Specifically, exposure to high glucose produces epigenetic changes in NSCs: histone H3K9 trimethylation, DNA methylation, and decreased histone H3K9 acetylation. These changes alter genes, such as $D c x$ and Pafahlb1, which regulate neural migration and microtubule formation in the cortex. Neurogenesis and neural migration are affected by these changes. ${ }^{59}$ Hyperglycemia also induces reactive oxygen species (ROS) production and intracellular oxidative stress in NSCs, altering the balance between their proliferation and apoptosis. ${ }^{60}$ Reduction of ROS is, therefore, one strategy to overcome NSC dysfunction during fetal development in the presence of high glucose.

\section{Hyperglycemic Impairments in Osteoprogenitor Cells}

In the bone microenvironment, after injury, diabetes has been found to impair blood supply to the fracture site undermining bony union. Diabetes also leads to increased bone resorption and osteopenia, significantly increasing the risk of fractures. ${ }^{61}$ Increased reactive oxygen stress and the formation of advanced glycation end products (AGEs) are found to underlie impaired osteoblast function and reduced formation of a mineralized matrix. Although literature on progenitor impairments in diabetic fracture healing remains sparse, preliminary evidence suggests that both skeletal stem cell dysfunction and impaired recruitment of vascular progenitor cells are central to poor healing outcomes after bony injury. ${ }^{62}$

\section{Hyperglycemic Impairments in Cardiac Stem Cells}

Diabetes has been found to impair growth reserves of the heart by activating ROS-induced apoptosis of cardiac progenitor cells (CPCs), leading to cardiac aging and failure. ${ }^{63}$ The dramatic loss of CPCs correlates with premature myocyte senescence and death, resulting in cardiac myopathy and characterized by a decrease in cardiac muscle mass, chamber dilation, and impaired ventricular function. Diabetes also causes telomere shortening in $\mathrm{CPCs}$, accelerating cell 
aging. ${ }^{64,65}$ Ablation of P66shc, a gene that critically regulates ROS and cellular lifespan, has been found to prevent hyperglycemia-induced loss of CPCs and increase resistance of CPCs to oxidative stress and apoptosis. These reports provide evidence that $\mathrm{CPC}$ alterations after diabetes negatively affect the health of the heart.

\section{Single-Cell Studies Reveal Progenitor Cell Subpopulation Deficits after Diabetes}

Diabetes alters the intrinsic properties of stem cells, impairing their function and therapeutic capacity. In the skin, for example, population-based studies of transplanted diabetic adipose-derived stem cells (ASCs) from mice demonstrate decreased proliferation, migration, and growth factor production, with an inability to promote keratinocyte and fibroblast proliferation and migration. ${ }^{66}$ However, stem cells and progenitor cells are complex cell populations associated with functional heterogeneity. Traditional population-level assays, such as microarray or immunoblotting, that involve pooling of RNA or protein from hundreds of thousands of cells report aggregate expression of data. The resolution afforded by these assays is insufficient to capture the complex relationships in heterogeneous samples, and is unable to detect differential expression among cell subgroups ${ }^{67,68}$ Single cells within seemingly homogeneous populations exhibit differences not only in their gene expression, but also in protein levels and phenotypic output, shifting functional consequences of the population. Although methods such as flow cytometry have been able to interrogate protein expression on single cells, the rate-limiting factor is the number of proteins that can be tested at a time.

Only recently have high-throughput techniques evolved to interrogate samples with single-cell resolution. These systems, such as the Biomark HD for gene expression, $\mathrm{C} 1$ for single cell RNA-sequencing, Juno for single-nucleotide polymorphism genotyping, ${ }^{69}$ and CyTOF2 for multiparametric mass spectrometry (all from Fluidigm, South San Francisco, CA), make use of micro-fluidic technology to achieve massively parallel single-cell analysis. These evolving techniques provide novel insights into the relationships among individual cells in complex tissues. ${ }^{70}$ The rapidly evolving single-cell RNA-sequencing technique, for example, is a powerful approach that precisely determines cellular variations on the basis of transcriptome-wide changes, and helps identify functionally important, but rare, cellular responses. ${ }^{71,72}$

Single-cell gene expression allows for identification of cells objectively without a priori knowledge of biomarkers. When combined with advanced mathematical modeling, it allows for the characterization of heterogeneity within putatively homogeneous progenitor populations, and identifies critical perturbations in these cell subpopulations on exposure to various stimuli. ${ }^{73-76}$
By using the Fluidigm Biomark, which analyzes the transcription of 96 genes, our group has detected single-cell changes in diabetic murine and human ASCs. ${ }^{14}$ Similarly, single-cell gene expression analysis of wild-type bone marrow progenitor cells has identified differences in key genes related to ischemic neovascularization. ${ }^{55}$ These results suggest that selective subpopulation depletion is a potential mechanism for the impairment of diabetic progenitor-vasculogenic potential. Furthermore, selective subpopulation enrichment may be used to support vasculogenesis for therapeutic application.

\section{Molecular Pathways that Underlie Stem Cell Dysfunction during Diabetes}

A distinct stromal cell microenvironment, termed the niche, harbors the stem cell and is found to regulate cell-intrinsic signaling and extrinsic cues, determining stem cell fate and function. ${ }^{19,20}$ In most stem cell systems, the organization of the niche remains only partly uncovered. In the bone marrow, for example, MSCs are thought to maintain the HSC niche. ${ }^{20}$ Herein, they regulate the quiescence, proliferative potential, differentiation fate, and trafficking of HSCs. ${ }^{19}$ In the skin, multipotent hair follicular stem cells that are responsible for regenerating hair follicles, interfollicular epidermis, and sebaceous glands after wounding form a niche for melanocyte stem cells. ${ }^{10}$

Diabetes is thought to negatively affect stem cell niches, altering stem cell dynamics and disrupting homeostasis and repair. Predominantly, changes in ROS and hypoxia from neighboring cells in the presence of excessive glucose alter juxtacrine and paracrine signaling to the stem cells. ${ }^{77,78}$ Moreover, diabetes causes an influx of inflammatory cells and stimulates adipocyte production, altering the stem cell microenvironment. ${ }^{79}$ These molecular changes are addressed in this section.

\section{ROS}

Diabetic hyperglycemia affects a wide range of cell types. Because of the closely associated microvascular complications associated with diabetes, endothelial cell impairment is the most widely studied. At the molecular level, sustained exposure of cells to excessive levels of glucose produces increases in ROS. ${ }^{11}$ Three independent biochemical reactions arise as an outcome: glucose-induced activation of protein kinase $\mathrm{C}$ isoforms, increased glucose-derived AGEs, and increased glucose flux through the aldose-reductase pathway. ${ }^{11}$ Normalizing mitochondrial superoxide dismutase is found to block each of these three pathways, pointing toward a potential therapeutic avenue. ${ }^{80}$

Stem cells similarly exhibit changes in response to alterations in environmental and intracellular ROS. In health, stem cells exist in hypoxic niches and maintain low ROS levels by fine-tuning metabolic pathways, such as anaerobic glycolysis. ${ }^{81,82}$ Stem cells are also characterized by the 


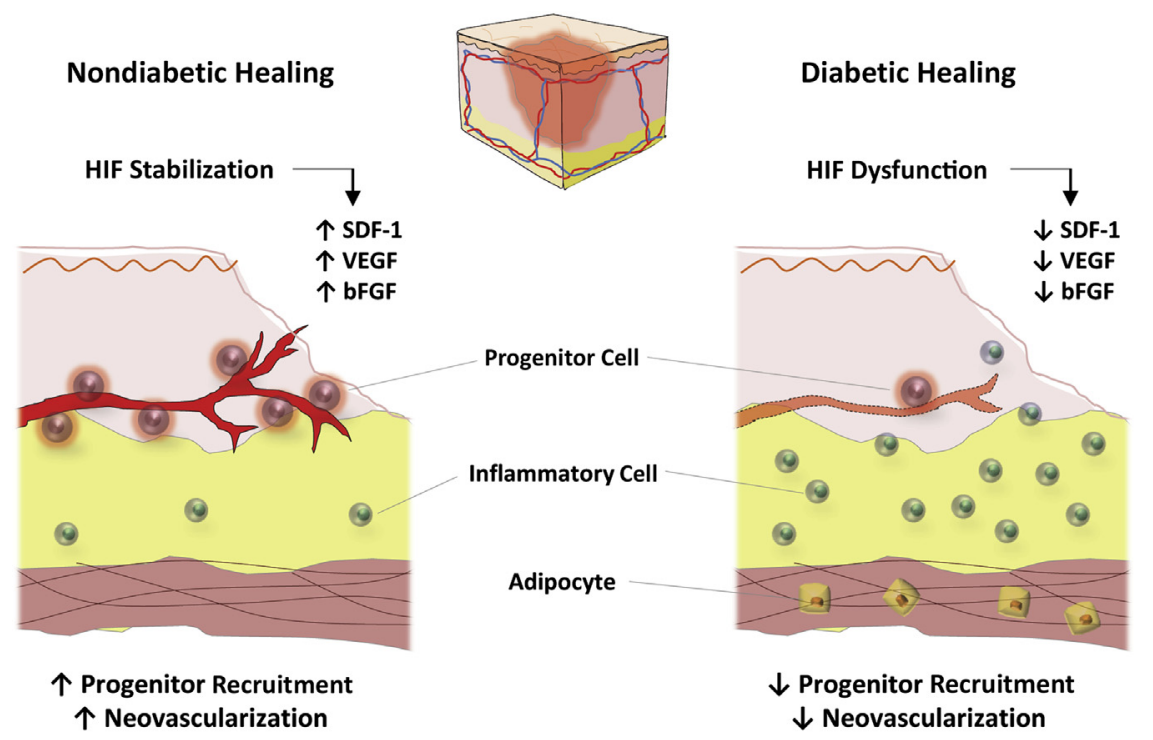

Figure 2 Diabetes disrupts progenitor cell recruitment. Diabetic wounds are characterized by decreased influx of progenitor cells and more inflammatory cells, resulting in impaired neovascularization and nonhealing wounds. bFGF, basic fibroblast growth factor; HIF, hypoxiainducible factor; SDF, stromal-derived factor; VEGF, vascular endothelial growth factor. presence of well-organized antioxidant defense systems. Collectively, the metabolic and antioxidant systems protect stem cells from extrinsic oxidative stress, maintaining quiescence. A modest increase in ROS activates selfrenewal and promotes differentiation, or initiates migration of stem/progenitor cells to regions of injury, leading to neovascularization and tissue repair.

Diabetes produces a surge in ROS, generating a prolonged inflammatory and oxidative environment. Increases in glucose and ROS cause accumulation of AGEs and impair functioning of the receptor for AGEs. AGE accumulation inhibits stem cell proliferation, and causes stem cell senescence, impairing innate tissue repair mechanisms. ${ }^{77,78}$ ROS exposure also produces epigenetic changes within stem cells, resulting in cellular senescence. ${ }^{83}$ These reports suggest that induction of oxidative stress within the niche contributes to reducing the angiogenic and vasculogenic potential of stem cells, leading to less efficient healing and revascularization. ${ }^{84}$

\section{HIF}

Hypoxia-Induced Impairments at the Site of Injury

The physiological response to local wound hypoxia plays a major role in determining the success of the normal healing process. At the site of tissue damage in response to hypoxia, there is stabilization of hypoxia-inducible factor (HIF) $1 \alpha$, the primary transcription factor of oxygen homeostasis that drives the transcription of several key genes. Active HIF-1 is a heterodimer comprising a hypoxia-stabilized $\alpha$-subunit (HIF-1 $\alpha$ ) and a constitutively expressed $\beta$-subunit (HIF-1 $\beta$ ). Stabilized HIF-1 $\alpha$ translocates to the nucleus and dimerizes with HIF-1 $\beta$, where it is activated by $\mathrm{p} 300$, after which it binds to a conserved and defined hypoxia response element. A cascade of genes, including vascular endothelial growth factor, basic fibroblast growth factor, and stromal-derived factor-1 (SDF1), are activated. Vascular endothelial growth factor and basic fibroblast growth factor activate angiogenesis by endothelial cells. SDF1 has been reported to mobilize circulating progenitors expressing $\mathrm{C}-\mathrm{X}-\mathrm{C}$ chemokine receptor 4 (the receptor for SDF1) toward the site of injury, where the cells engraft, release growth factors, and contribute to neovascularization. ${ }^{30,49,85,86}$

Diabetes causes the overproduction of superoxide anion and the accumulation of glycolytic metabolites, such as methylglyoxal. ${ }^{87}$ This alteration prevents the stabilization and activation of HIF, preventing HIF-mediated activation of vascular endothelial growth factor and SDF1 and resulting in impaired progenitor homing and poor neovascularization ${ }^{50,88}$ (Figure 2). Current literature suggests that the impaired recruitment of progenitors after diabetic injury contributes to decreased neovascularization and deficiencies in healing. ${ }^{85}$ Poor wound healing outcomes in diabetic patients stem, in part, from an inadequate response of progenitor cells to hypoxia.

Hypoxia-Induced Impairments within the Niche

Within the bone marrow stem cell niche, HIF-1 $\alpha$ stabilization maintains stem cell pluripotency by up-regulating genes, such as oct- 4 and klf- $4{ }^{89}$ HIF- $1 \alpha$ also controls HSC fate through close regulation of MSCs. In conditions of demand-driven hematopoiesis, HIF-1 $\alpha$ is specifically down-regulated in MSCs via a STAT-1-mediated mechanism, triggering expansion and differentiation of HSCs. ${ }^{90}$

Pathological destabilization and deficiencies in the hypoxic factor produce decreases in HSC numbers. ${ }^{91} \mathrm{HIF}-$ $1 \alpha$-deficient mice not only display loss of HSC cycle quiescence, but also show decreased HSC engraftment after bone marrow transplantation, in a p16Ink4a/p19Arfdependent manner. ${ }^{91}$ Although causality between HIF-1 $\alpha$ destabilization and progenitor dysfunction within niches, such as the bone marrow and adipose tissue, during diabetes has not been directly tested, reduced HIF-1 $\alpha$ in the setting of diabetes and reduced progenitor function within 

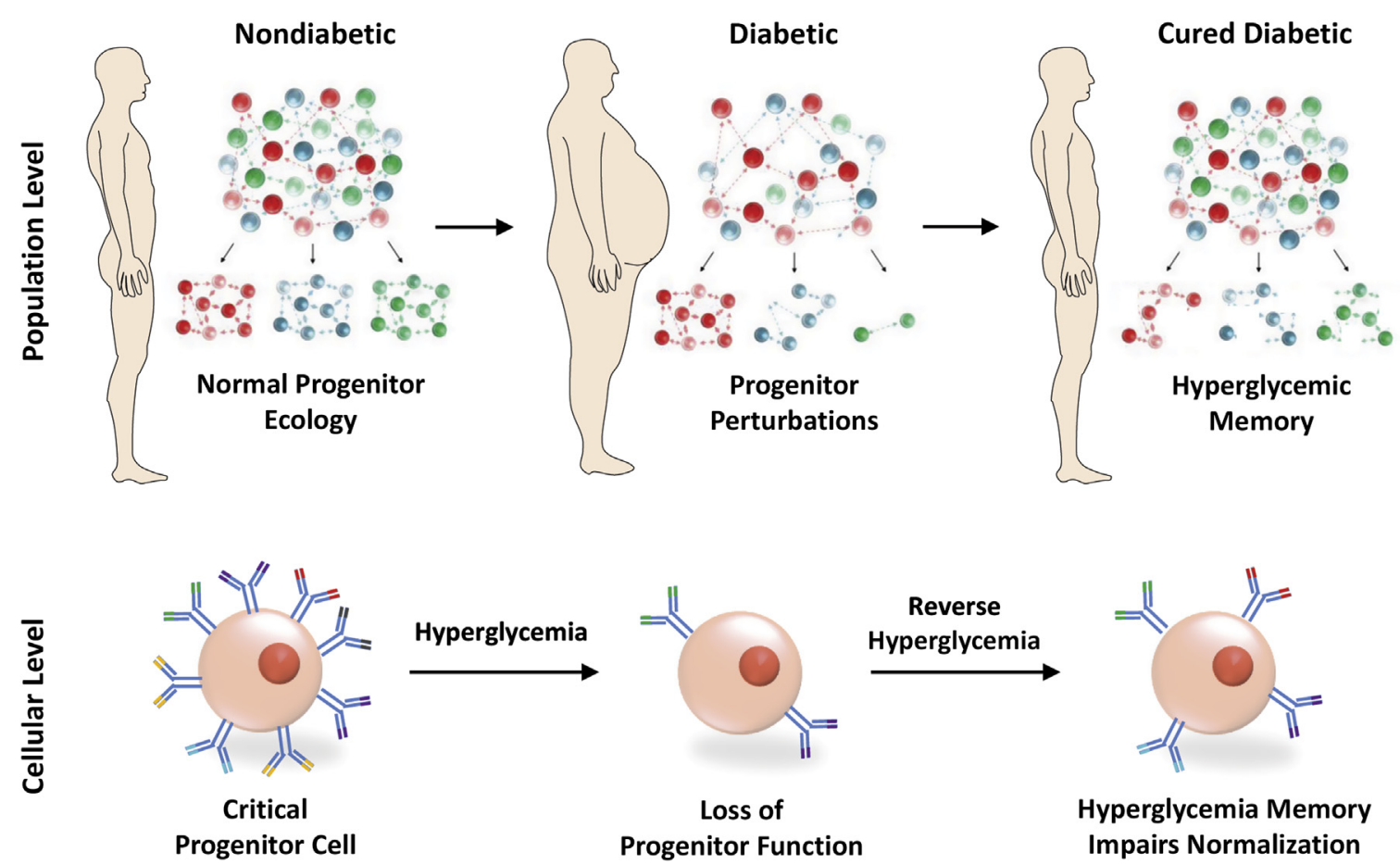

Figure 3 Diabetes causes population-wide and single-cell alterations within progenitor cells. Exposure to sustained hyperglycemia causes depletion of critical progenitor cell subsets and alterations within individual progenitor cells. Hyperglycemic memory prevents the normalization of progenitor function on curing of diabetes.

the niche suggest that regulation of hypoxia contributes to progenitor dysfunction.

\section{Increased Adipocyte Accumulation and Inflammation}

Accumulation of adipose tissue in obesity-induced type 2 diabetes attracts and harbors inflammatory cells. ${ }^{92,93}$ Specifically, diabetics display an increase in M1 macrophages within the adipose tissue and muscle that release proinflammatory factors, including tumor necrosis factor- $\alpha$, IL- $1 \beta$, and chemokine ligand $2 .{ }^{93}$ Concurrently, stem cells in the adipose tissue, bone marrow, and muscle that divide in hyperglycemia divert to pathological adipogenesis in response to glucose stress. ${ }^{94-97}$ Subsequent divisions of these proadipogenic diabetic stem cells could contribute to the extensive population of fat cells in adipose tissue. ${ }^{95}$ Moreover, the pro-adipogenic stem cells deposit extracellular matrix preferentially adhesive to monocytes. ${ }^{94}$ Thus, the inflammatory environment surrounding progenitor cells in the adipose tissue might play a role in shifting the differentiation outcomes of the stem cell.

\section{Diabetic Stem and Progenitor Cell Defects Are Reversible Only in Part}

Clinical data suggest that the control and treatment of diabetes through regulation of diet or bariatric surgery ameliorate some comorbidities. ${ }^{7,98-100}$ However, not all diabetic subjects under intensive glycemic control and treatment reduce the incidence and progression of tissue complications. ${ }^{8}$ Stem cells and progenitor cells are dysfunctional at both a population-wide and a single-cell level in diabetes. ${ }^{14}$ It would be expected, therefore, that correcting or treating diabetes will restore the function of these progenitors and prevent further tissue complications. However, this is not always the case. Although some clinical observations suggest a reversibility of diabetes-induced progenitor cell dysfunction, ${ }^{15,101}$ preclinical data indicate that progenitor cell deficits may be reversible only in part, after normalization of the glycemic environment. ${ }^{55}$

Normalizing glucose in vitro in bone marrow progenitor cell cultures or in vivo in type 1 diabetic mice by insulin treatment reveals these phenomena of partial reversal of function. ${ }^{55}$ Diabetic MSCs in normoglycemic conditions in vitro do not recover to wild-type baseline capacities in cytokine expression. ${ }^{55}$ Furthermore, the Sca- $1^{+} / \mathrm{CD} 45^{-} / \mathrm{Lin}^{-}$subpopulation of progenitors within the nonhematopoietic bone marrow compartment is reduced in number 6 months after normalization, despite hyperglycemic correction. ${ }^{55}$ A 16-hour exposure to hyperglycemia in vitro (on aortic endothelial cells) and a 6-hour exposure to hyperglycemia in vivo are sufficient to produce long-lasting epigenetic changes. ${ }^{102}$ Specifically, monomethylation of $\mathrm{H} 3 \mathrm{~K} 4$ in the proximal promoter of the NF$\kappa \mathrm{B}$ subunit $\mathrm{p} 65$ has been shown to cause sustained expression of p65 and p65-dependent inflammatory genes. Similarly, demethylation of a histone lysine residue in the proximal p65 promoter $\mathrm{H} 3 \mathrm{~K} 9$ produces a reduced inhibition of $\mathrm{p} 65$ and acts 
synergistically with the H3K4 modification to produce increased inflammation, modifying cell signaling. ${ }^{102}$ These epigenetic changes are stimulated by an overproduction of hyperglycemia-induced ROS and are carried onto daughter cells.

The effects of hyperglycemia on cells are not limited to adult tissue alone. Stem cell dysregulation has been found to be causative for congenital anomalies that occur in the fetus because of the presence of diabetes in the pregnant mother. Murine studies show that once the blastocyst has been exposed to hyperglycemia, exertion of tight glycemic control is insufficient to prevent or reverse congenital defects that have already occurred. ${ }^{59}$

Given the impairments within progenitor cells during diabetes, the impact of hyperglycemic reversal on cell functionality is crucially important for designing targeted therapeutics. Specifically, if cells display hyperglycemic memory suggestive of permanent modifications that are passed to daughter cells, the translational potential for autologous therapies may be limited. With access to healthy, diabetic, and post-bariatric surgery patients, our group has been able to study human progenitor cell biology in the prediabetic, diabetic, and corrected-diabetic state. Preliminary data from our first 40 patients demonstrate unique progenitor cell subpopulations, and dysregulation of these progenitors on morbid obesity and diabetes. ${ }^{103}$

Taken together, hyperglycemic memory of progenitors suggests that cellular alterations are not always completely reversible (Figure 3). A cure for diabetes is, therefore, insufficient to preserve progenitor capacity and prevent diabetic complications in all cases if genetic changes in response to sustained hyperglycemia have already taken hold.

\section{Treating Diabetic Complications}

Various stem and progenitor cells have been tested in preclinical studies and have shown promise in treating secondary complications associated with diabetes. Diabetic retinopathy, the most frequent cause of new blindness in adults, is a severe ocular complication. Embryonic stem cells, HSCs, bone marrow-MSCs, and ASCs have been used to treat diabetic retinopathy and macular degeneration by promoting retinal neovascularization in small animals. ${ }^{104}$ Similarly, bone marrow-MSC and ASC transplants have been tested for the modulation of diabetic nephropathy and for the treatment of nonhealing diabetic wounds resulting from neuropathy and microvasculopathy. ${ }^{14,105,106}$ This section details the various approaches of using autologous stem cells for treating diabetic complications.

\section{Enriched Progenitor Cell Subpopulation Therapy}

From a therapeutic standpoint, enrichment of autologous progenitor subsets that have retained their neovascularization and regenerative potential is an emerging choice for transplants. Fundamentally, enrichment of subpopulations is accomplished through the inclusion of surface marker genes in the transcriptional query, followed by linear discriminate analysis to determine the surface markers most closely mirroring expression of critical subpopulation defining genes. $^{68,103}$

The feasibility of this approach has been demonstrated by transplanting a subpopulation of human ASCs enriched for genes related to osteogenesis, for reconstruction of bone. ${ }^{73}$ Similarly, a subpopulation of murine ASCs with enhanced wound healing potential has been transplanted for treating diabetic wounds in mice. ${ }^{103}$ As predicted transcriptionally, prospective enrichment for these ASC subpopulations and application in diabetic wounds enhance therapeutic efficacy, resulting in the restoration of normal healing kinetics in diabetic wounds. Conversely, depleting this population impairs the therapeutic potential of these cells, strongly suggesting that alterations in stem cell subpopulations contribute to impaired healing. ${ }^{103}$

Despite the promising outcomes, the main challenge with using enriched autologous stem cell subpopulations for treating diabetic complications is the severe limitation of cell numbers. This opens avenues for preconditioning of autologous stem cells before transplant.

\section{Preconditioning Stem Cells with HIF}

Because Hif- $1 \alpha$ destabilization contributes to the collapse of progenitor function during diabetes, one approach of overcoming progenitor dysfunction is by stabilizing Hif activation. Both the deficiency and overexpression of Hif have pathological outcomes, with Hif overexpression leading to fibrosis during healing. ${ }^{107}$ The ideal balance would be a sustained lowlevel stabilization of Hif, which can be achieved through smallmolecule therapy, such as deferoxamine (DFO). DFO, an iron chelator, shown to improve healing in diabetic mice, has been tested for improvement of progenitor function. ${ }^{88,108}$ Treatment of bone marrow-derived MSCs from streptozocin-diabetic rats with DFO in vitro elevates Hif- $1 \alpha$ levels and increases the expression of the homing receptors $\mathrm{C}-\mathrm{X}$-C chemokine receptor 4 and CCR2. DFO treatment also increases the activity of the matrix metalloproteases 2 and 9, important for matrix breakdown and cell invasion. DFO-treated diabetic MSCs migrate and home to injury faster in vivo compared with untreated MSCs. In HSCs, DFO has been used to reduce iron load, reduce ROS levels, and attenuate apoptosis. ${ }^{109}$ These reports suggest that sustained low-level DFO pretreatment ex vivo could improve the efficacy of autologous MSC therapy.

\section{Reversing Progenitor Function by Targeting AGEs}

Another approach of preconditioning stem cells is by targeting the AGE pathway. During diabetes, because of the increased glucose flux, there is an accumulation of glyceraldehyde-3phosphate intermediates that are nonenzymatically degraded into the reactive aldehyde, methylglyoxal. Methylglyoxal 
increases oxidative stress and leads to the formation of AGEs. Glyoxalase-1 is the enzyme that eliminates methylglyoxal; its overexpression prevents diabetic neuropathy, retinopathy, and microvascular complications. ${ }^{110}$ This approach has been extended to treat stem cells exposed to hyperglycemia. Overexpression of bone marrow cells with glyoxalase- 1 and protection from methylglyoxal are sufficient in restoring the neovascular potential of diabetic bone marrow cells and cardiac stem cells. ${ }^{111}$ Similarly, reducing intake of AGEs in the diet restricts both insulin resistance and inflammation, modulating hyperglycemic memory. ${ }^{112}$

Other methods of overcoming AGE-induced dysfunction and apoptosis in diabetic bone marrow cells have also been tested. Pretreatment of hyperglycemia-exposed bone marrow MSCs with pirfenidone, a tumor necrosis factor- $\alpha$ blocker, and $\mathrm{N}$-acetyl-L-cysteine can counter ROS-induced inflammation and progenitor apoptosis through modulation of AGEs. ${ }^{78}$

Taken together, preclinical data suggest that enriched autologous progenitor cell subsets preconditioned in vitro to metabolically withstand a high-glucose, high-ROS environment are a promising approach for treating diabetic complications. In the event where sufficient numbers of critical autologous progenitor subsets cannot be obtained, readily available banked allogenic progenitors from adult bone marrow, adipose tissue, or blood, or from umbilical cord blood or placenta, might serve as alternative sources of cell-based therapy.

\section{Conclusions}

Diabetes remains the seventh leading cause of death in the United States, ${ }^{1}$ requiring treatment modalities that will curb disease progression. Closer cellular analysis underlying diabetic complications reveals that stem and progenitor cells are adversely affected by the constant exposure to high levels of glucose. These adverse changes are outcomes of a microenvironment high in ROS, inflammation, hypoxia, and AGE products. Progenitor cells faced with an altered environment exhibit changes in their quiescence, cell cycle, differentiation, and migration abilities, negatively affecting both tissue homeostasis and repair after injury. Furthermore, altered progenitor function correlates with poor clinical outcomes after diabetes.

Our recent reports, validated by high-throughput singlecell analyses, suggest that progenitor dysfunction is a result of specific progenitor cell subpopulation-depletion, rather than loss and modification of the entire progenitor pool. Other reports suggest that intensive glycemic control in some patients is found to reduce the incidence and progression of progenitor dysfunction; however, the outcomes do not normalize to individuals without diabetes. The cellular alterations that follow exposure to high glucose are not completely reversible because progenitor cells retain hyperglycemic memory. Epigenetic mechanisms, advanced glycation, and changes in the oxidative state of the cellular microenvironment provide clues toward explaining the pathogenesis of hyperglycemic memory in progenitor cells.

There are several drawbacks in studying these complex pathological changes that occur within the stem cells. Current in vitro studies involve mirroring of the diabetic environment by exposure of stem cells to media with high glucose. These studies are unable to recapitulate the complex changes in the stem cell niche comprising other cell types and its effect on the stem cell. Furthermore, such studies make it highly difficult to study well-controlled diabetes, the most common form of diabetes today. Murine models have their own drawbacks, with epigenetic pathways and diabetic outcomes varying with the genetic background. ${ }^{113}$ The use of high-fat diet-induced diabetes in mice helps eliminate some of these anomalies, and allows for a system of strict regulation of diet. Clinical studies, especially studies monitoring stem cell function over extending periods of time, are especially valuable and open avenues for further elucidation of stem cell dysfunction in diabetic complications.

Taken together, we conclude that curing diabetes is insufficient to completely preserve progenitor capacity and prevent diabetic complications in all cases, especially if genetic changes in response to hyperglycemia have already taken hold.

\section{References}

1. Centers for Disease Control and Prevention: National diabetes statistics report: estimates of diabetes and its burden in the United States, 2014. Atlanta, GA, U.S. Department of Health and Human Services. Available at http://www.cdc.gov/diabetes/pubs/statsreport14/ national-diabetes-report-web.pdf. Accessed May 4, 2015

2. UK Prospective Diabetes Study (UKPDS) Group: Effect of intensive blood-glucose control with metformin on complications in overweight patients with type 2 diabetes (UKPDS 34). Lancet 1998, 352: 854-865

3. UK Prospective Diabetes Study (UKPDS) Group: Intensive bloodglucose control with sulphonylureas or insulin compared with conventional treatment and risk of complications in patients with type 2 diabetes (UKPDS 33). Lancet 1998, 352:837-853

4. Skyler JS, Bergenstal R, Bonow RO, Buse J, Deedwania P, Gale EA, Howard BV, Kirkman MS, Kosiborod M, Reaven P, Sherwin RS; American Diabetes Association, American College of Cardiology Foundation, American Heart Association: Intensive glycemic control and the prevention of cardiovascular events: implications of the ACCORD, ADVANCE, and VA Diabetes Trials: a position statement of the American Diabetes Association and a Scientific Statement of the American College of Cardiology Foundation and the American Heart Association. J Am Coll Cardiol 2009, 53:298-304

5. The Diabetes Control and Complications Trial Research Group: The effect of intensive treatment of diabetes on the development and progression of long-term complications in insulin-dependent diabetes mellitus. N Engl J Med 1993, 329:977-986

6. Huang ES, Liu JY, Moffet HH, John PM, Karter AJ: Glycemic control, complications, and death in older diabetic patients: the diabetes and aging study. Diabetes Care 2011, 34:1329-1336 
7. Hsu WC, Lau KH, Matsumoto M, Moghazy D, Keenan H, King GL: Improvement of insulin sensitivity by isoenergy high carbohydrate traditional Asian diet: a randomized controlled pilot feasibility study. PLoS One 2014, 9:e106851

8. Tonna S, El-Osta A, Cooper ME, Tikellis C: Metabolic memory and diabetic nephropathy: potential role for epigenetic mechanisms. Nat Rev Nephrol 2010, 6:332-341

9. Yong TY, Phillipov G, Phillips PJ: Management outcomes of patients with type 2 diabetes: targeting the 10-year absolute risk of coronary heart disease. Med J Aust 2007, 186:622-624

10. Tanimura S, Tadokoro $\mathrm{Y}$, Inomata K, Binh NT, Nishie W, Yamazaki S, Nakauchi H, Tanaka Y, McMillan JR, Sawamura D, Yancey K, Shimizu H, Nishimura EK: Hair follicle stem cells provide a functional niche for melanocyte stem cells. Cell Stem Cell 2011, 8:177-187

11. Brownlee M: Biochemistry and molecular cell biology of diabetic complications. Nature 2001, 414:813-820

12. Brem H, Tomic-Canic M: Cellular and molecular basis of wound healing in diabetes. J Clin Invest 2007, 117:1219-1222

13. Ferraro F, Lymperi S, Mendez-Ferrer S, Saez B, Spencer JA, Yeap BY, Masselli E, Graiani G, Prezioso L, Rizzini EL, Mangoni M, Rizzoli V, Sykes SM, Lin CP, Frenette PS, Quaini F, Scadden DT: Diabetes impairs hematopoietic stem cell mobilization by altering niche function. Sci Transl Med 2011, 3:104ral

14. Rennert RC, Sorkin M, Januszyk M, Duscher D, Kosaraju R, Chung MT, Lennon J, Radiya-Dixit A, Raghvendra S, Maan ZN, Hu MS, Rajadas J, Rodrigues M, Gurtner GC: Diabetes impairs the angiogenic potential of adipose-derived stem cells by selectively depleting cellular subpopulations. Stem Cell Res Ther 2014, 5:79

15. Hernandez SL, Gong JH, Chen L, Wu IH, Sun JK, Keenan HA, King GL: Characterization of circulating and endothelial progenitor cells in patients with extreme-duration type 1 diabetes. Diabetes Care 2014, 37:2193-2201

16. Seita J, Weissman IL: Hematopoietic stem cell: self-renewal versus differentiation. Wiley Interdiscip Rev Syst Biol Med 2010, 2: 640-653

17. Oguro H, Ding L, Morrison SJ: SLAM family markers resolve functionally distinct subpopulations of hematopoietic stem cells and multipotent progenitors. Cell Stem Cell 2013, 13:102-116

18. Pittenger MF, Mackay AM, Beck SC, Jaiswal RK, Douglas R, Mosca JD, Moorman MA, Simonetti DW, Craig S, Marshak DR: Multilineage potential of adult human mesenchymal stem cells. Science 1999, 284:143-147

19. Mendez-Ferrer S, Michurina TV, Ferraro F, Mazloom AR, Macarthur BD, Lira SA, Scadden DT, Ma'ayan A, Enikolopov GN, Frenette PS: Mesenchymal and haematopoietic stem cells form a unique bone marrow niche. Nature 2010, 466:829-834

20. Morrison SJ, Scadden DT: The bone marrow niche for haematopoietic stem cells. Nature 2014, 505:327-334

21. Crisan M, Yap S, Casteilla L, Chen CW, Corselli M, Park TS, Andriolo G, Sun B, Zheng B, Zhang L, Norotte C, Teng PN, Traas J, Schugar R, Deasy BM, Badylak S, Buhring HJ, Giacobino JP, Lazzari L, Huard J, Peault B: A perivascular origin for mesenchymal stem cells in multiple human organs. Cell Stem Cell 2008, 3: 301-313

22. Crisan M, Chen CW, Corselli M, Andriolo G, Lazzari L, Peault B: Perivascular multipotent progenitor cells in human organs. Ann N Y Acad Sci 2009, 1176:118-123

23. Chan CK, Lindau P, Jiang W, Chen JY, Zhang LF, Chen CC, Seita J, Sahoo D, Kim JB, Lee A, Park S, Nag D, Gong Y, Kulkarni S, Luppen CA, Theologis AA, Wan DC, DeBoer A, Seo EY, VincentTompkins JD, Loh K, Walmsley GG, Kraft DL, Wu JC, Longaker MT, Weissman IL: Clonal precursor of bone, cartilage, and hematopoietic niche stromal cells. Proc Natl Acad Sci U S A 2013, 110:12643-12648

24. Chan CK, Seo EY, Chen JY, Lo D, McArdle A, Sinha R, Tevlin R, Seita J, Vincent-Tompkins J, Wearda T, Lu WJ, Senarath-Yapa K,
Chung MT, Marecic O, Tran M, Yan KS, Upton R, Walmsley GG, Lee AS, Sahoo D, Kuo CJ, Weissman IL, Longaker MT: Identification and specification of the mouse skeletal stem cell. Cell 2015, 160:285-298

25. Tondreau T, Meuleman N, Delforge A, Dejeneffe M, Leroy R, Massy M, Mortier C, Bron D, Lagneaux L: Mesenchymal stem cells derived from CD133-positive cells in mobilized peripheral blood and cord blood: proliferation, Oct 4 expression, and plasticity. Stem Cells 2005, 23:1105-1112

26. Hoogduijn MJ, Verstegen MM, Engela AU, Korevaar SS, Roemeling-van Rhijn M, Merino A, Franquesa M, de Jonge J, Ijzermans JN, Weimar W, Betjes MG, Baan CC, van der Laan LJ: No evidence for circulating mesenchymal stem cells in patients with organ injury. Stem Cells Dev 2014, 23:2328-2335

27. Li S, Huang KJ, Wu JC, Hu MS, Sanyal M, Hu M, Longaker MT, Lorenz HP: Peripheral blood-derived mesenchymal stem cells: candidate cells responsible for healing critical-sized calvarial bone defects. Stem Cells Transl Med 2015, 4:359-368

28. Asahara T, Murohara T, Sullivan A, Silver M, van der Zee R, Li T, Witzenbichler B, Schatteman G, Isner JM: Isolation of putative progenitor endothelial cells for angiogenesis. Science 1997, 275: 964-967

29. Asahara T, Masuda H, Takahashi T, Kalka C, Pastore C, Silver M, Kearne M, Magner M, Isner JM: Bone marrow origin of endothelial progenitor cells responsible for postnatal vasculogenesis in physiological and pathological neovascularization. Circ Res 1999, 85: $221-228$

30. Ceradini DJ, Kulkarni AR, Callaghan MJ, Tepper OM, Bastidas N, Kleinman ME, Capla JM, Galiano RD, Levine JP, Gurtner GC: Progenitor cell trafficking is regulated by hypoxic gradients through HIF-1 induction of SDF-1. Nat Med 2004, 10:858-864

31. Schmidt A, Brixius K, Bloch W: Endothelial precursor cell migration during vasculogenesis. Circ Res 2007, 101:125-136

32. Rehman J, Li J, Orschell CM, March KL: Peripheral blood "endothelial progenitor cells" are derived from monocyte/macrophages and secrete angiogenic growth factors. Circulation 2003, 107:1164-1169

33. Purhonen S, Palm J, Rossi D, Kaskenpaa N, Rajantie I, YlaHerttuala S, Alitalo K, Weissman IL, Salven P: Bone marrow-derived circulating endothelial precursors do not contribute to vascular endothelium and are not needed for tumor growth. Proc Natl Acad Sci U S A 2008, 105:6620-6625

34. Cheung TH, Rando TA: Molecular regulation of stem cell quiescence. Nat Rev Mol Cell Biol 2013, 14:329-340

35. Rodgers JT, King KY, Brett JO, Cromie MJ, Charville GW, Maguire KK, Brunson C, Mastey N, Liu L, Tsai CR, Goodell MA, Rando TA: mTORC1 controls the adaptive transition of quiescent stem cells from G0 to G(Alert). Nature 2014, 510:393-396

36. Rossi L, Lin KK, Boles NC, Yang L, King KY, Jeong M, Mayle A, Goodell MA: Less is more: unveiling the functional core of hematopoietic stem cells through knockout mice. Cell Stem Cell 2012, 11:302-317

37. Beerman I, Seita J, Inlay MA, Weissman IL, Rossi DJ: Quiescent hematopoietic stem cells accumulate DNA damage during aging that is repaired upon entry into cell cycle. Cell Stem Cell 2014, 15: $37-50$

38. Malam Z, Cohn RD: Stem cells on alert: priming quiescent stem cells after remote injury. Cell Stem Cell 2014, 15:7-8

39. Wang YH, Israelsen WJ, Lee D, Yu VW, Jeanson NT, Clish CB, Cantley LC, Vander Heiden MG, Scadden DT: Cell-state-specific metabolic dependency in hematopoiesis and leukemogenesis. Cell 2014, 158:1309-1323

40. Folmes CD, Dzeja PP, Nelson TJ, Terzic A: Metabolic plasticity in stem cell homeostasis and differentiation. Cell Stem Cell 2012, 11: 596-606

41. Folmes CD, Nelson TJ, Martinez-Fernandez A, Arrell DK, Lindor JZ, Dzeja PP, Ikeda Y, Perez-Terzic C, Terzic A: Somatic 
oxidative bioenergetics transitions into pluripotency-dependent glycolysis to facilitate nuclear reprogramming. Cell Metab 2011, $14: 264-271$

42. Zhang J, Khvorostov I, Hong JS, Oktay Y, Vergnes L, Nuebel E, Wahjudi PN, Setoguchi K, Wang G, Do A, Jung HJ, McCaffery JM, Kurland IJ, Reue K, Lee WN, Koehler CM, Teitell MA: UCP2 regulates energy metabolism and differentiation potential of human pluripotent stem cells. EMBO J 2011, 30: 4860-4873

43. Gurumurthy S, Xie SZ, Alagesan B, Kim J, Yusuf RZ, Saez B, Tzatsos A, Ozsolak F, Milos P, Ferrari F, Park PJ, Shirihai OS, Scadden DT, Bardeesy N: The Lkb1 metabolic sensor maintains haematopoietic stem cell survival. Nature 2010, 468:659-663

44. Tang AH, Rando TA: Induction of autophagy supports the bioenergetic demands of quiescent muscle stem cell activation. EMBO J 2014, 33:2782-2797

45. Nuschke A, Rodrigues M, Stolz DB, Chu CT, Griffith L, Wells A: Human mesenchymal stem cells/multipotential stromal cells consume accumulated autophagosomes early in differentiation. Stem Cell Res Ther 2014, 5:140

46. Wang C, Liang CC, Bian ZC, Zhu Y, Guan JL: FIP200 is required for maintenance and differentiation of postnatal neural stem cells. Nat Neurosci 2013, 16:532-542

47. Rubinsztein DC, Marino G, Kroemer G: Autophagy and aging. Cell 2011, 146:682-695

48. Yang L, Li P, Fu S, Calay ES, Hotamisligil GS: Defective hepatic autophagy in obesity promotes ER stress and causes insulin resistance. Cell Metab 2010, 11:467-478

49. Ceradini DJ, Gurtner GC: Homing to hypoxia: HIF-1 as a mediator of progenitor cell recruitment to injured tissue. Trends Cardiovasc Med 2005, 15:57-63

50. Thangarajah H, Vial IN, Grogan RH, Yao D, Shi Y, Januszyk M, Galiano RD, Chang EI, Galvez MG, Glotzbach JP, Wong VW, Brownlee M, Gurtner GC: HIF-1alpha dysfunction in diabetes. Cell Cycle 2010, 9:75-79

51. Capla JM, Grogan RH, Callaghan MJ, Galiano RD, Tepper OM, Ceradini DJ, Gurtner GC: Diabetes impairs endothelial progenitor cell-mediated blood vessel formation in response to hypoxia. Plast Reconstr Surg 2007, 119:59-70

52. El-Ftesi S, Chang EI, Longaker MT, Gurtner GC: Aging and diabetes impair the neovascular potential of adipose-derived stromal cells. Plast Reconstr Surg 2009, 123:475-485

53. Lerman OZ, Galiano RD, Armour M, Levine JP, Gurtner GC: Cellular dysfunction in the diabetic fibroblast: impairment in migration, vascular endothelial growth factor production, and response to hypoxia. Am J Pathol 2003, 162:303-312

54. Fadini GP, Albiero M, Vigili de Kreutzenberg S, Boscaro E, Cappellari R, Marescotti M, Poncina N, Agostini C, Avogaro A: Diabetes impairs stem cell and proangiogenic cell mobilization in humans. Diabetes Care 2013, 36:943-949

55. Januszyk M, Sorkin M, Glotzbach JP, Vial IN, Maan ZN, Rennert RC, Duscher D, Thangarajah H, Longaker MT, Butte AJ, Gurtner GC: Diabetes irreversibly depletes bone marrow-derived mesenchymal progenitor cell subpopulations. Diabetes 2014, 63: 3047-3056

56. Spinetti G, Cordella D, Fortunato O, Sangalli E, Losa S, Gotti A, Carnelli F, Rosa F, Riboldi S, Sessa F, Avolio E, Beltrami AP, Emanueli C, Madeddu P: Global remodeling of the vascular stem cell niche in bone marrow of diabetic patients: implication of the microRNA155/FOXO3a signaling pathway. Circ Res 2013, 112:510-522

57. Yue WS, Lau KK, Siu CW, Wang M, Yan GH, Yiu KH, Tse HF: Impact of glycemic control on circulating endothelial progenitor cells and arterial stiffness in patients with type 2 diabetes mellitus. Cardiovasc Diabetol 2011, 10:113

58. Zabihi S, Loeken MR: Understanding diabetic teratogenesis: where are we now and where are we going? Birth Defects Res A Clin Mol Teratol 2010, 88:779-790
59. Shyamasundar S, Jadhav SP, Bay BH, Tay SS, Kumar SD, Rangasamy D, Dheen ST: Analysis of epigenetic factors in mouse embryonic neural stem cells exposed to hyperglycemia. PLoS One 2013, 8:e65945

60. Fu J, Tay SS, Ling EA, Dheen ST: Aldose reductase is implicated in high glucose-induced oxidative stress in mouse embryonic neural stem cells. J Neurochem 2007, 103:1654-1665

61. Vestergaard P, Rejnmark L, Mosekilde L: Relative fracture risk in patients with diabetes mellitus, and the impact of insulin and oral antidiabetic medication on relative fracture risk. Diabetologia 2005, 48:1292-1299

62. Tevlin R, Mc Ardle A, Senarath-Yapa K, Rodrigues M, Maan ZN Li S, Chan CK, Brunski J, Gurtner GC: Impaired angiogenesis: a critical contributor to problematic fracture healing in diabetes. J Am Coll Surg 2014, 219:S83

63. Messina E, Giacomello A: Diabetic cardiomyopathy: a "cardiac stem cell disease" involving p66Shc, an attractive novel molecular target for heart failure therapy. Circ Res 2006, 99:1-2

64. Rota M, LeCapitaine N, Hosoda T, Boni A, De Angelis A, Padin-Iruegas ME, Esposito G, Vitale S, Urbanek K, Casarsa C, Giorgio M, Luscher TF, Pelicci PG, Anversa P, Leri A, Kajstura J: Diabetes promotes cardiac stem cell aging and heart failure, which are prevented by deletion of the p66shc gene. Circ Res 2006, 99:42-52

65. Menini S, Amadio L, Oddi G, Ricci C, Pesce C, Pugliese F, Giorgio M, Migliaccio E, Pelicci P, Iacobini C, Pugliese G: Deletion of p66Shc longevity gene protects against experimental diabetic glomerulopathy by preventing diabetes-induced oxidative stress. Diabetes 2006, 55:1642-1650

66. Cianfarani F, Toietta G, Di Rocco G, Cesareo E, Zambruno G, Odorisio T: Diabetes impairs adipose tissue-derived stem cell function and efficiency in promoting wound healing. Wound Repair Regen 2013, 21:545-553

67. Warren L, Bryder D, Weissman IL, Quake SR: Transcription factor profiling in individual hematopoietic progenitors by digital RT-PCR Proc Natl Acad Sci U S A 2006, 103:17807-17812

68. Januszyk M, Gurtner GC: High-throughput single-cell analysis for wound healing applications. Adv Wound Care 2013, 2: 457-469

69. Blainey PC, Quake SR: Dissecting genomic diversity, one cell at a time. Nat Methods 2014, 11:19-21

70. Ottesen EA, Hong JW, Quake SR, Leadbetter JR: Microfluidic digital PCR enables multigene analysis of individual environmental bacteria. Science 2006, 314:1464-1467

71. Shalek AK, Satija R, Shuga J, Trombetta JJ, Gennert D, Lu D, Chen P, Gertner RS, Gaublomme JT, Yosef N, Schwartz S, Fowler B, Weaver S, Wang J, Wang X, Ding R, Raychowdhury R, Friedman N, Hacohen N, Park H, May AP, Regev A: Single-cell RNA-seq reveals dynamic paracrine control of cellular variation. Nature 2014, 510: 363-369

72. Shalek AK, Satija R, Adiconis X, Gertner RS, Gaublomme JT, Raychowdhury R, Schwartz S, Yosef N, Malboeuf C, Lu D, Trombetta JJ, Gennert D, Gnirke A, Goren A, Hacohen N, Levin JZ, Park H, Regev A: Single-cell transcriptomics reveals bimodality in expression and splicing in immune cells. Nature 2013, 498:236-240

73. Levi B, Wan DC, Glotzbach JP, Hyun J, Januszyk M, Montoro D, Sorkin M, James AW, Nelson ER, Li S, Quarto N, Lee M, Gurtner GC, Longaker MT: CD105 protein depletion enhances human adipose-derived stromal cell osteogenesis through reduction of transforming growth factor beta1 (TGF-beta1) signaling. J Biol Chem 2011, 286:39497-39509

74. Glotzbach JP, Januszyk M, Vial IN, Wong VW, Gelbard A, Kalisky T, Thangarajah H, Longaker MT, Quake SR, Chu G, Gurtner GC: An information theoretic, microfluidic-based single cell analysis permits identification of subpopulations among putatively homogeneous stem cells. PLoS One 2011, 6:e21211 
75. Suga H, Rennert RC, Rodrigues M, Sorkin M, Glotzbach JP, Januszyk M, Fujiwara T, Longaker MT, Gurtner GC: Tracking the elusive fibrocyte: identification and characterization of collagenproducing hematopoietic lineage cells during murine wound healing. Stem Cells 2014, 32:1347-1360

76. Huang W, Cao X, Biase FH, Yu P, Zhong S: Time-variant clustering model for understanding cell fate decisions. Proc Natl Acad Sci U S A 2014, 111:E4797-E4806

77. Chen J, Song M, Yu S, Gao P, Yu Y, Wang H, Huang L: Advanced glycation endproducts alter functions and promote apoptosis in endothelial progenitor cells through receptor for advanced glycation endproducts mediate overpression of cell oxidant stress. Mol Cell Biochem 2010, 335:137-146

78. Weinberg E, Maymon T, Weinreb M: AGEs induce caspase-mediated apoptosis of rat BMSCs via TNFalpha production and oxidative stress. J Mol Endocrinol 2014, 52:67-76

79. Donath MY, Shoelson SE: Type 2 diabetes as an inflammatory disease. Nat Rev Immunol 2011, 11:98-107

80. Nishikawa T, Edelstein D, Du XL, Yamagishi S, Matsumura T, Kaneda Y, Yorek MA, Beebe D, Oates PJ, Hammes HP, Giardino I, Brownlee M: Normalizing mitochondrial superoxide production blocks three pathways of hyperglycaemic damage. Nature 2000, 404: $787-790$

81. Ito K, Suda T: Metabolic requirements for the maintenance of selfrenewing stem cells. Nat Rev Mol Cell Biol 2014, 15:243-256

82. Takubo K, Nagamatsu G, Kobayashi CI, Nakamura-Ishizu A, Kobayashi H, Ikeda E, Goda N, Rahimi Y, Johnson RS, Soga T, Hirao A, Suematsu M, Suda T: Regulation of glycolysis by Pdk functions as a metabolic checkpoint for cell cycle quiescence in hematopoietic stem cells. Cell Stem Cell 2013, 12:49-61

83. Cesselli D, Beltrami AP: Stem cell senescence in diabetes: forgetting the sweet old memories. Diabetes 2014, 63:1841-1843

84. Ushio-Fukai M, Rehman J: Redox and metabolic regulation of stem/progenitor cells and their niche. Antioxid Redox Signal 2014, 21:1587-1590

85. Kang L, Chen Q, Wang L, Gao L, Meng K, Chen J, Ferro A, Xu B: Decreased mobilization of endothelial progenitor cells contributes to impaired neovascularization in diabetes. Clin Exp Pharmacol Physiol 2009, 36:e47-e56

86. Fadini GP, Sartore S, Schiavon M, Albiero M, Baesso I, Cabrelle A, Agostini C, Avogaro A: Diabetes impairs progenitor cell mobilisation after hindlimb ischaemia-reperfusion injury in rats. Diabetologia 2006, 49:3075-3084

87. Thangarajah H, Yao D, Chang EI, Shi Y, Jazayeri L, Vial IN, Galiano RD, Du XL, Grogan R, Galvez MG, Januszyk M, Brownlee M, Gurtner GC: The molecular basis for impaired hypoxiainduced VEGF expression in diabetic tissues. Proc Natl Acad Sci U S A 2009, 106:13505-13510

88. Loh SA, Chang EI, Galvez MG, Thangarajah H, El-ftesi S, Vial IN, Lin DA, Gurtner GC: SDF-1 alpha expression during wound healing in the aged is HIF dependent. Plast Reconstr Surg 2009, 123: $65 \mathrm{~S}-75 \mathrm{~S}$

89. Park IH, Kim KH, Choi HK, Shim JS, Whang SY, Hahn SJ, Kwon OJ, Oh IH: Constitutive stabilization of hypoxia-inducible factor alpha selectively promotes the self-renewal of mesenchymal progenitors and maintains mesenchymal stromal cells in an undifferentiated state. Exp Mol Med 2013, 45:e44

90. Guarnerio J, Coltella N, Ala U, Tonon G, Pandolfi PP, Bernardi R: Bone marrow endosteal mesenchymal progenitors depend on HIF factors for maintenance and regulation of hematopoiesis. Stem Cell Reports 2014, 2:794-809

91. Takubo K, Goda N, Yamada W, Iriuchishima H, Ikeda E, Kubota Y, Shima H, Johnson RS, Hirao A, Suematsu M, Suda T: Regulation of the HIF-1alpha level is essential for hematopoietic stem cells. Cell Stem Cell 2010, 7:391-402

92. Ramkhelawon B, Hennessy EJ, Menager M, Ray TD, Sheedy FJ, Hutchison S, Wanschel A, Oldebeken S, Geoffrion M, Spiro W,
Miller G, McPherson R, Rayner KJ, Moore KJ: Netrin-1 promotes adipose tissue macrophage retention and insulin resistance in obesity. Nat Med 2014, 20:377-384

93. Osborn O, Olefsky JM: The cellular and signaling networks linking the immune system and metabolism in disease. Nat Med 2012, 18 363-374

94. Wang A, Midura RJ, Vasanji A, Wang AJ, Hascall VC: Hyperglycemia diverts dividing osteoblastic precursor cells to an adipogenic pathway and induces synthesis of a hyaluronan matrix that is adhesive for monocytes. J Biol Chem 2014, 289:11410-11420

95. Hascall V, Wang A: Hyperglycemia diverts dividing stem cells to pathological adipogenesis. Stem Cell Res Ther 2014, 5:128

96. Onate B, Vilahur G, Camino-Lopez S, Diez-Caballero A, BallestaLopez C, Ybarra J, Moscatiello F, Herrero J, Badimon L: Stem cells isolated from adipose tissue of obese patients show changes in their transcriptomic profile that indicate loss in stemcellness and increased commitment to an adipocyte-like phenotype. BMC Genomics 2013, $14: 625$

97. Yan J, Tie G, Wang S, Messina KE, DiDato S, Guo S, Messina LM: Type 2 diabetes restricts multipotency of mesenchymal stem cells and impairs their capacity to augment postischemic neovascularization in db/db mice. J Am Heart Assoc 2012, 1:e002238

98. Sjostrom L, Lindroos AK, Peltonen M, Torgerson J, Bouchard C, Carlsson B, Dahlgren S, Larsson B, Narbro K, Sjostrom CD, Sullivan M, Wedel H: Lifestyle, diabetes, and cardiovascular risk factors 10 years after bariatric surgery. N Engl J Med 2004, 351: $2683-2693$

99. Sjostrom CD, Lissner L, Wedel H, Sjostrom L: Reduction in incidence of diabetes, hypertension and lipid disturbances after intentional weight loss induced by bariatric surgery: the SOS Intervention Study. Obes Res 1999, 7:477-484

100. Robinson MK: Surgical treatment of obesity: weighing the facts. N Engl J Med 2009, 361:520-521

101. Hortenhuber T, Rami-Mehar B, Satler M, Nagl K, Hobaus C, Hollerl F, Koppensteiner R, Schernthaner G, Schober E, Schernthaner GH: Endothelial progenitor cells are related to glycemic control in children with type 1 diabetes over time. Diabetes Care 2013, 36:1647-1653

102. Brasacchio D, Okabe J, Tikellis C, Balcerczyk A, George P, Baker EK, Calkin AC, Brownlee M, Cooper ME, El-Osta A: Hyperglycemia induces a dynamic cooperativity of histone methylase and demethylase enzymes associated with gene-activating epigenetic marks that coexist on the lysine tail. Diabetes 2009, 58: $1229-1236$

103. Sorkin MRR, Januszyk M, Glotzbach JP, Chung MT, Longaker MT, Gurtner GC: Cell surface marker profiling of human adipose derived stem cells using single cell transcriptional analysis identifies heterogenous subpopulations. J Am Coll Surg 2013, 217: S96-S97

104. Megaw R, Dhillon B: Stem cell therapies in the management of diabetic retinopathy. Curr Diab Rep 2014, 14:498

105. Shibata T, Naruse K, Kamiya H, Kozakae M, Kondo M, Yasuda Y, Nakamura N, Ota K, Tosaki T, Matsuki T, Nakashima E, Hamada Y, Oiso Y, Nakamura J: Transplantation of bone marrow-derived mesenchymal stem cells improves diabetic polyneuropathy in rats. Diabetes 2008, 57:3099-3107

106. Davey GC, Patil SB, O'Loughlin A, O'Brien T: Mesenchymal stem cell-based treatment for microvascular and secondary complications of diabetes mellitus. Front Endocrinol (Lausanne) 2014, $5: 86$

107. Hong WX, Hu MS, Esquivel M, Liang GY, Rennert RC, McArdle A, Paik KJ, Duscher D, Gurtner GC, Lorenz HP, Longaker MT: The role of hypoxia-inducible factor in wound healing. Adv Wound Care 2014, 3:390-399

108. Duscher D, Neofytou E, Wong VW, Maan ZN, Rennert RC, Inayathullah M, Januszyk M, Rodrigues M, Malkovskiy AV, Whitmore AJ, Walmsley GG, Galvez MG, Whittam AJ, 
Brownlee M, Rajadas J, Gurtner GC: Transdermal deferoxamine prevents pressure-induced diabetic ulcers. Proc Natl Acad Sci U S A 2015, 112:94-99

109. Lu W, Zhao M, Rajbhandary S, Xie F, Chai X, Mu J, Meng J, Liu Y, Jiang Y, Xu X, Meng A: Free iron catalyzes oxidative damage to hematopoietic cells/mesenchymal stem cells in vitro and suppresses hematopoiesis in iron overload patients. Eur J Haematol 2013, 91: 249-261

110. Brouwers O, Niessen PM, Miyata T, Ostergaard JA, Flyvbjerg A, Peutz-Kootstra CJ, Sieber J, Mundel PH, Brownlee M, Janssen BJ, De Mey JG, Stehouwer CD, Schalkwijk CG: Glyoxalase-1 overexpression reduces endothelial dysfunction and attenuates early renal impairment in a rat model of diabetes. Diabetologia 2014, 57: 224-235

111. Vulesevic B, McNeill B, Geoffrion M, Kuraitis D, McBane JE, Lochhead M, Vanderhyden BC, Korbutt GS, Milne RW, Suuronen EJ: Glyoxalase-1 overexpression in bone marrow cells reverses defective neovascularization in STZ-induced diabetic mice. Cardiovasc Res 2014, 101:306-316

112. Vlassara H, Striker GE: AGE restriction in diabetes mellitus: a paradigm shift. Nat Rev Endocrinol 2011, 7:526-539

113. Fornoni A, Striker LJ, Zheng F, Striker GE: Reversibility of glucoseinduced changes in mesangial cell extracellular matrix depends on the genetic background. Diabetes 2002, 51:499-505 